\title{
Necrosis of the gastrocnemius muscle in microscopic polyangiitis
}

\author{
Takahiko Akagi, ${ }^{1}$ Hirotake Nishimura, ${ }^{2}$ Tomoyuki Mukai, ${ }^{1}$ Yoshitaka Morita ${ }^{1}$
}

'Department of Rheumatology, Kawasaki Medical School, Kurashiki, Japan

${ }^{2}$ Department of Pathology, Kawasaki Medical School, Kurashiki, Japan

\section{Correspondence to}

Dr Yoshitaka Morita,

morita@med.kawasaki-m.ac.jp

Accepted 17 January 2018

\section{DESCRIPTION}

A 59-year-old man presented with a 1-month history of bilateral lower leg pain. The pain was more severe in the left leg, with associated swelling of the lower leg. He did not have any eye, nose, paranasal sinus or respiratory symptoms. Physical examination of the chest and abdomen was unremarkable. Neurological examination was normal. He had a body temperature of $36.5^{\circ} \mathrm{C}$, a blood pressure of $97 / 71 \mathrm{~mm} \mathrm{Hg}$, and a pulse of 77 beats $/ \mathrm{min}$. Blood tests revealed a C-reactive protein level of $155 \mathrm{mg} / \mathrm{L}$, leucocyte count of $10.3 \times 10^{9} / \mathrm{L}$ (neutrophil count $8.4 \times 10^{9} / \mathrm{L}$ ), haemoglobin level of $14.2 \mathrm{~g} / \mathrm{dL}$ and platelet count of $328 \times 10^{9} /$ L. Serum creatine kinase and lactate dehydrogenase levels were slightly elevated at $237 \mathrm{U} / \mathrm{L}$ (normal 41-153) and 231U/L (124-222), respectively. Serum creatinine was $0.51 \mathrm{mg} / \mathrm{dL}$. Serum complement (C3 and $\mathrm{C} 4)$ concentrations were normal. Antinuclear antibody and myeloperoxidase-specific antineutrophil cytoplasmic antibody (ANCA) were negative. Proteinase 3-specific ANCA was positive with a titre of $241 \mathrm{U} / \mathrm{mL}$ (normal <3.5). Urinalysis showed $2+$ haematuria and $1+$ proteinuria with a few granular casts, red blood cell casts and white blood cell casts. Plain X-ray and high-resolution CT of the chest showed no pulmonary abnormality. MRI revealed diffuse oedema in the left gastrocnemius muscle.

Biopsy of the left gastrocnemius muscle revealed a small-vessel vasculitis composed of fibrinoid necrosis and infiltration of inflammatory cells in the arterial walls (figure 1A). The muscle tissues were clearly divided into necrotic lesions and normal muscle fibres, and necrotic vasculitis was found near the infarct-like muscle lesions (figure 1B). A

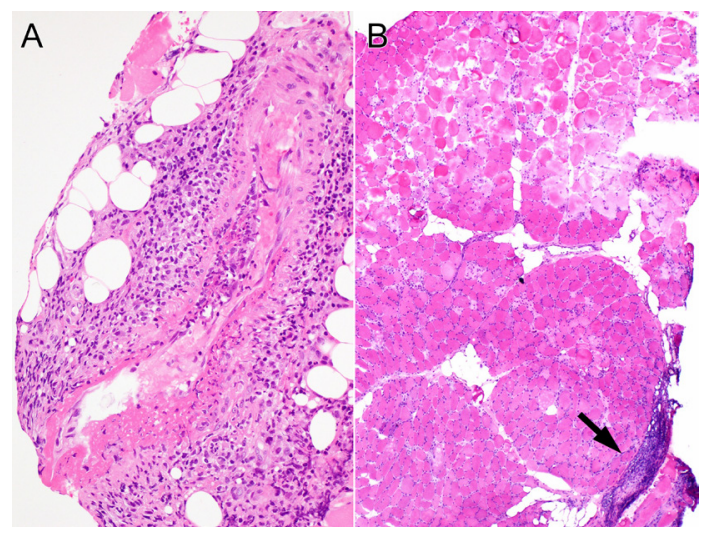

Figure 1 A gastrocnemius muscle biopsy specimen. H\&E staining showed (A) small-vessel vasculitis and (B) ischaemic infarct-like necrotic changes. Necrotic vasculitis was seen in the same biopsy specimen (arrow).

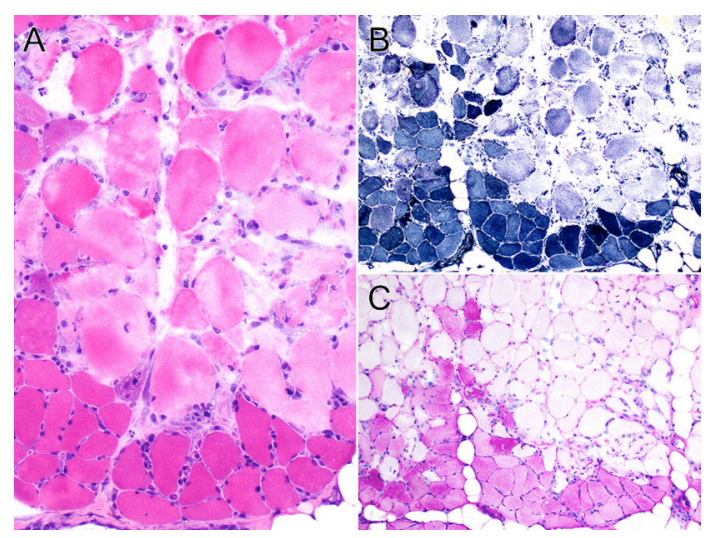

Figure 2 Ischaemic necrotic muscle tissues stained with (A) H\&E, (B) nicotinamide adenine dinucleotide tetrazolium reductase and $(C)$ periodic acid-Schiff.

diagnosis of muscle necrosis associated with smallvessel vasculitis was considered. The necrotic muscle tissue did not react with nicotinamide adenine dinucleotide tetrazolium reductase or with glycogen on periodic acid-Schiff staining, which also supported muscle ischaemia (figure 2). No granuloma was observed. A diagnosis of ANCA-positive microscopic polyangiitis was made. The patient was successfully treated with prednisolone $50 \mathrm{mg} /$ day and intravenous cyclophosphamide, followed by methotrexate.

Small to medium-sized vessel vasculitis can develop in the skeletal muscle of the lower limb. Our case is unusual in that a muscle biopsy revealed ischaemic infarct-like necrosis. A clinicopathological review of 40 cases of skeletal muscle vasculitis identified neurogenic muscle atrophy in the majority (95\%) of biopsy specimens but did not describe muscle necrosis. ${ }^{1}$ A literature search revealed only one report of muscle necrosis in ANCA-negative microscopic polyangiitis. ${ }^{2}$ The reason why muscle necrosis is uncommon in skeletal muscle vasculitis has yet to be identified. More reports on skeletal muscle vasculitis and investigations in experimental

\section{Learning points}

Small to medium-sized vessel vasculitis can develop in the skeletal muscle of the lower limbs.

- Neurogenic muscle atrophy is observed in the majority of biopsy specimens from patients with skeletal muscle vasculitis, but muscle necrosis is uncommon. 
animal models are needed to better understand the histopathological findings in this disease.

Contributors $T A, H N$ and $Y M$ are involved in conception or design of the work. TA and $\mathrm{HN}$ are responsible for acquisition of data. TA, HN, TM and YM are responsible for analysis and interpretation of data. TA, TM and YM drafted or revised the manuscript.

Funding This research received no specific grant from any funding agency in the public, commercial or not-for-profit sectors.

Competing interests TA, TM and YM received scholarship donations from AbbVie, Actelion, Astellas, Bristol-Myers, Chugai, Daiichi-Sankyo, Eisai, Eli Lilly, Japan Blood Products Organization, Mitsubishi-Tanabe, MSD, Pfizer, Shionogi, Takeda, Teijin and UCB
Patient consent Obtained.

Provenance and peer review Not commissioned; externally peer reviewed.

(C) BMJ Publishing Group Ltd (unless otherwise stated in the text of the article) 2018. All rights reserved. No commercial use is permitted unless otherwise expressly granted.

\section{REFERENCES}

1 Prayson RA. Skeletal muscle vasculitis exclusive of inflammatory myopathic conditions: a clinicopathologic study of 40 patients. Hum Pathol 2002;33:989-95.

2. Benz N, Daikeler T, Frank S, et al. Three cases of primary small vessel vasculitis of the skeletal muscle-an own entity. BMJ Case Rep 2011;2011:bcr0820114631.

Copyright 2017 BMJ Publishing Group. All rights reserved. For permission to reuse any of this content visit http://group.bmj.com/group/rights-licensing/permissions.

BMJ Case Report Fellows may re-use this article for personal use and teaching without any further permission.

Become a Fellow of BMJ Case Reports today and you can:

- Submit as many cases as you like

- Enjoy fast sympathetic peer review and rapid publication of accepted articles

- Access all the published articles

- Re-use any of the published material for personal use and teaching without further permission

For information on Institutional Fellowships contact consortiasales@bmjgroup.com

Visit casereports.bmj.com for more articles like this and to become a Fellow 